\title{
KARYA SASTRA MUTAKHIR DENGAN KAJIAN PENDEKATAN GENDER
}

\author{
Setyawan Pujiono*
}

\begin{abstract}
Gender is a concept used to identify the differences between men and women. It has a strong relationship with literary work, that stories are employed by authors to communicate their messages and ideas from women. The results of the creativity are strongly influenced by the socio cultural condition of the authors. Female authors try to actively cooperate in responding the development of gender issues and using the chances to express their creative ideas into their literary works. Authors mean to change the gender issues perception through their literature works to make female equal to men in socio construction community.

Female literary works are used as media in motivating women to do something to express their ideas so that women figures become a part of this real world who has the right to consider and admired. Recently, female literary works are almost equal to men's in Indonesian literary world as a figure to show that women are not weak as what our community thought in patriarchy culture.

Studies in female literary works such as Ayu Utami, Dewi Dee, and Djenar Maesa Ayu have given new colors in literary world. The colors are very useful agents of a change for women specially to life equal in the socio constructions community in the future.
\end{abstract}

Keyword: Ayu Utami, Dewi Dee, and Djenar Maesa Ayu, female literary, gender, and the socio cultural condition,

*Staf Pengajar Prodi Pendidikan Bahasa dan Sastra Indonesia Fakultas Bahasa dan Seni Universitas Negeri Yogyakarta. 


\section{A. Pendahuluan}

Kajian tentang dunia perempuan dalam teks sastra Indonesia terfokus pada batasan pemahaman tentang konsep cerita dalam karya sastra. Dalam proses kreatifnya sistem budaya di Indonesia selalu terkait dengan norma, patriarkhi, yang terdapat dalam kebudayaan, pemerintahan, agama dan kehidupan sosial kemasyarakatan (Mansour, 1996: 3) ${ }^{1}$. Hal tersebut muncul karena pengaruh dari berbagai ragam individu, kelompok/masyarakat, dan pengaruh global. Persoalan yang menjadi keterbatasan informasi tentang gender dapat dilihat dengan terbatasnya karya-karya satra berbasis perempuan.

Seorang anak ketika dilahirkan kedunia, maka pada saat itu sudah dapat dikenali, apakah seorang anak laki-laki ataukah anak perempuan berdasarkan jenis kelaminnya. Jika anak tersebut mempunyai penis berarti berjenis kelamin laki-laki, tetapi jika mempunyai vagina, maka berjenis kelamin perempuan. Pada saat seorang anak dilahirkan, maka ia akan memperoleh tugas dan beban gender dari lingkungan sosial budaya dalam masyarakat. Di masyarakat umumnya menganggap beban bagi gender laki-laki lebih dominan daripada gender perempuan.

Sebagai sarana pengkajian gender, maka penulis akan mencoba mengkaji karya sastra mutakhir dengan pendekatan gender. Di dalam karya sastra bias gender sering dimunculkan oleh penulis melalui tokoh dalam cerita. Oleh sebab itu, penulis tertarik untuk mengupas kajian bias gender dalam cerita teks sastra. Karya sastra yang merupakan sarana pengungkapan ide-ide, gagasan, dan pandangan bagi sastrawan. Hasil proses kreatif tersebut dipengaruhi oleh keadaan sosial budaya pengarang. Dengan demikian karya sastra yang merupakan hasil ekspresi pengarang

${ }^{1}$ Fakih, Mansour. Analisis gender dan Transformasi Sosial. Yogyakarta. Pustaka Pelajar. 1996. hlm. 3. 
dimungkinkan dari latar belakang sosial budayanya. Karya-karya kreatif dalam karya sastra perempuan, menggambarkan kehidupan dunia perempuan yang ingin terlepas dari belenggu ketidakadilan laki-laki.

\section{B. Perspektif Gender}

Pengertian kata gender berasal dari bahasa inggris "gender" yang berarti “jenis kelamin”. Dalam dictionary, gender diartikan sebagai perbedaan yang tampak antara laki-laki dan perempuan di lihat dari sudut pandang nilai dan tingkah laku. Di dalam encyclopedia dijelaskam bahwa gender adalah suatu konsep kulltural yang berupaya membuat perbedaan (distinction) dalam hal peran, perilaku, mentalitas dan karakteristik emosional antara laki-laki dan perempuan yang berkembang dalam masyarakat. $^{2}$ Menurut Hilary $M$, menyatakan bahwa gender diartikan sebagai harapan-harapan budaya terhadap laki-laki dan perempuan.

Untuk mendapatkan pengertian yang jelas, maka kita dapat menyimpulkan beberapa pengertian di atas bahwa gender adalah suatu konsep yang digunakan untuk mengidentifikasi perbedaan laki-laki dan perempuan. Perbedaan ini dilihat dari sudut pandang sosial dan budaya. Gender dalam hal ini membahas tentang perbedaan lakilaki dan perempuan dari sudut non-biologis. Gender merupakan perbedaan laki-laki dan perempuan di pandang dari struktur sosial di masyarakat.

Secara umum karya sastra dimaksudkan sebagai gambaran hidup manusia ketika di dunia. Kehidupan manusia tersebut dapat berupa kehidupan dalam lingkungan kelauarga, masyarakat, kerja dan sebagainya. Kehidupan manusia dalam lingkungan tersebut berupa perilaku sosial antara individu satu dengan individu lain dan atau kelampok lain. Manusia diciptakan dalam dua jenis, pria dan wanita, sehingga interaksi sosial yang ada tidak terbatas dalam satu jenis kelamin.

\footnotetext{
${ }^{2}$ Nasarudin. 1999. Argumen Kesetaraan Jender. Jakarta: Paramadina. hlm. 33.
} 
Perbedaan jenis kelamin tersebut tentunya mempunyai fungsi dan peran yang berbeda-beda. Akan tetapi, perbedaan tersebut akan membedakan berbagai aktivitas, peran, kedudukan, dan kehormatan dalam lingkungannya masing-masing. Hal-hal tersebut seringkali muncul di teks cerita karya sastra yang tujuannya untuk membangun cerita agar menjadi lebih meanarik dan hidup.

Di sisi lain, seorang sastrawan merupakan pemikir yang mempunyai daya imajinasi dan kekritisan terhadap fenomena sosial budaya yang melingkupinya. Penyajian karya sastra, berupaya untuk menunjukkan dan menggambarkan realitas sosial yang sesuai dan tidak sesuai dengan nilai yang berlaku dalam masyarakat. Sastrawan dalam berkarya tidak hanya dipengaruhi budaya yang ada, namun juga mampu mempengaruhi ilmu pengetahuan, teknologi, hubungan sosial (Ahmadi: 2002: 19) $)^{3}$.

Banyaknya pesan yang ingin disampaikan sastrawan melalui tulisannya kepada masyarakat menjadikan dasar pengkajian bias gender dalam teks sastra. Kajian tersebut yaitu tentang bias gender yang terdapat dalam karya sastra mutakhir/modern Indonesia. Melalui pendekatan tekstual inilah, maka kajian ini akan mendeskripsikan bias gender yang terdapat dalam teks sastra melalui cerita di dalamnya.

Pemahaman gender yang dipengaruhi perubahan sosial, ataupun kultur budaya disikapi penulis perempuan dengan menciptakan teks cerita yang mempunyai tema gender. Hasil karya sastra tersebut sebagai media dalam mengekspresikan realita kehidupan perempuan sebagai luapan kesah para kaum perempuan yang mendapatkan perlakuaan tidak adil oleh laki-laki dan budaya yang membelenggunya.

Secara umum karya sastra dikatakan sebagai gambaran hidup manusia. Kehidupan manusia tersebut dapat berupa kehidupan dalam lingkup keluarga, masyarkat, organisasi, pemerintahan dan sebagainya. Kehidupan tersebut berupa

\footnotetext{
${ }^{3}$ Ahmadi, A. Psikologi Sosial. Jakarta: Rineka Cipta. 2002. hlm. 19.
} 
interaksi antara individu satu dengan individu lain atau interaksi dengan kelompok satu dengan kelompok lainnya.

\section{Karya Sastra Perempuan}

Beberapa karya sastra karya perempuan merupakan sebuah jawaban dari kehidupan dunia perempuan dalam bersastra. Penulis perempuan mencoba berperaan aktif dalam menanggapi dan merespon perkembangan gender dan menggunakan peluang untuk mengungkapkan ide-ide kreatifnya ke dalam karya sastra. Pemikiran kreatif penulis perempuan tersebut dalam menciptakan karyanya menggambarkan realita kehidupan secara kodrati sebagai perempuan, dan ungkapan tentang ketidak adilan perlakuan laki-laki terhadap perempuan di masyarakat sekarang ini.

Jika kita melihat beberapa penulis perempuan seperti; Ayu Utami dengan Saman dan Larung-nya serta Dewi Lestari dengan Supernova, Djenar Maesa Ayu dengan mereka bilang saya monyet, tidaklah selalu bahwa karya-karya pengarang tersebut sesuai dengan pendekatan jender. Meskipun mereka dengan karya-karyanya dikenal sebagai tokoh sastrawan perempuan yang ingin menunjukkan pada dunia bahwa kaum perempuan adalah sama dengan laki-laki. Sudut pandang kesamaan tersebut tentunya ditunjukkan melalui konstruksi sosial masyarakat yang membelenggunya. Melaui cerita dan penokohan yang menarik, penulis ingin membuktikan bahwa perempuan mampu sejajar dengan laki-laki.

Hal tersebut dapat kita lihat karya-karya Djenar Maesa Ayu dalam Antologi cerpennya berjudul “Mereka Bilang Saya Monyet”. Dalam karyanya berisikan cerita tentang kedisharmonisan keluarga akibat siksaan dari kaum laki-laki. Djenar Maesa Ayu ${ }^{4}$, mencoba melakukan pertentangan dengan kodratnya sebagai seorang

\footnotetext{
${ }^{4}$ Maesa, A. Mereka Bilang, Saya Monyet (antologi cerpen). Gramedia Pustaka Utama. Jakarta. 2003.
} 
perempuan untuk menentang kaum laki-laki yang mengakibatkan ketidakharmonisan dalam keluarga. Selain itu, dalam buku tersebut hampir semua cerpen dalam antologinya tersebut bertokoh utama perempuan, mereka adalah perempuan kelas menengah dan atas yang tinggal dan hidup di dunia metropolitan yang menderita karena menjadi korban kekerasan seksual dan ketidakadilan budaya patriarkhi.

Korban yang ditunjukkan dalam cerita tersebut adalah anak-anak dan perempuan. Korban tersebut berasal dari keluarga broken home yang kerap berselingkuh dengan laki-laki. Djenar Maesa Ayu (dalam antologinya), mencoba menuliskan kegundahan yang ada relevansinya dengan apa yang ia lihat sebagai seorang perempuan dan ia merasa masih banyak hal yang masih deskriminatif karena masalah keluarga, tindak kekerasan, tindakan seksualitas, yang dapat menimbulkan disharmonis dalam keluarga. Cerpen-cerpennya yang bercerita tentang perbedaan perempuan dan laki-laki dan merupakan biografi psikologi dari segala hal yang ia rasakan dan bisa dipertanggungjawabkan.

Meskipun ia menyebutnya bukan sesuatu yang salah, namun pendekatan yang cenderung dipaksakan tersebut telah menyebabkan adanya keterbatasan dalam menafsirkan dan mengukur kualitas karya perempuan, sehingga karya tersebut seakan-akan berada sebagai sejarah yang terpisah, tidak terbaca dalam ruang pemahaman yang lebih leluasa. "Kualitas karya-karya perempuan cenderung dilihat dengan kriteria sejauh mana karya tersebut berbeda dengan laki-laki karena menyuarakan keperempuanan, atau sejauh mana ia resisten terhadap dunia laki-laki, baik dalam bentuk maupun isi.

Sementara itu, untuk melakukan analisis yang mendalam atas feminisme dalam kontek konstruksi sosial dan kesejarahannya terdapat keterangan bahwa

\footnotetext{
${ }^{5}$ Maesa, A. Mereka Bilang, Saya Monyet (antologi cerpen). Gramedia Pustaka Utama. Jakarta. 2003.
} 
feminisme dengan ide-ide kesadarannya ditujukan untuk melihat adanya dominasi atas dunia perempuan yang tak pernah diberi tempat untuk menjadi sejajar dengan laki-laki. Kaum perempuan lebih cenderung di pandang sebagai kaum termarginal yang terkungkung dalam aktivitas yang terbatas di bawah kaum laki-laki. Keberanian perempuan untuk mengungkapakan ide-idenya tersebut merupakan bentuk luapan pengetahuan di masa yang lalu.

Karya sastra yang ditulis oleh para penulis (perempuan) yang terjadi akhirakhir ini, dengan membongkar tabu narasi-narasi seks dan sebagai representasi perlawanan atas dominasi budaya patriarkhi, bisa dilihat sebagai bagian utuh dari gagasan kesadaran seperti itu, atau justru memperlihatkan adanya semacam kesalahan pemahaman feminis. Hal tersebut menyebabkan keadaan itu berada di luar konteks moralitas budayanya yang nantinya akan berakibat tidak baik bagi diri penulis. Ketidaksetaraan yang selama ini digambarkan melalui cerita-cerita dalam antologi cerpen karya Djenar Maesa Ayu, akan mendobrak dunia kesastraan dari sudut pandang gender.

Cerita sastra sebagai bentuk komunikasi narasi, semestinya dapat dinilai dari pengaruhnya terhadap masyarakat sekitarnya. Cerita tersebut semestinya mampu memberikan inspirasi dan analogi positif bagi pembaca atau peminat sastra. Manfaat karya sastra dapat dirasakan, jika karya sastra tersebut di dukung oleh keinginan menikmati dan penilaian masyarakat di mana karya itu berada. Akan tetapi, fenomena sekarang ini, unsur kapitalisme dan kepentingan pribadi juga sangat berperan menentukan atau mengarahkan publik. Hal tersebut menyebabkan pesan cerita yang disampaikan dalam karya sastra menjadi berkurang kebermaknaannya.

Kesamaan dari sisi feminisme novelis perempuan adalah keberaniannya dalam mengemas konstruksi sosial dan seks dalam bungkus yang benar-benar berbeda. Mereka berani melawan tabu yang selama ini menjadi magma terpendam 
pada masyarakat yang sarat dengan keberagaman budaya. Seks menarik justru karena melanggar kenormalan dalam masyarakat tradisional. Adapun gender, terbentuk sarat dengan peran dan konstruksi kaum laki-laki di atas kaum perempuan ${ }^{6}$ (Wiyatmi, 2004: 3). Melalui perlawanan terhadap tabu dan konstruksi sosial ini, mereka meretas fenomena kekerasan tersamar terhadap perempuan, terutama dalam hal seksualitas dan peranannya. Peran tersebut terdapat dalam keluarga, masyarakat dan bingkai organisasi yang mengungkungnya..

Kehadiran buku-buku tentang dunia perempuan, gender, dan seks membuat masyarakat peminat sastra semakin dekat. Citra informasi yang disajikan dalam bentuk cerita menjadikan kajian penting dari dua sudut pandang. Penulis perempuan cenderung membela dan memberontak terhadap budaya dan konstruksi sosial yang selama ini ada. Akan tetapi, kaum laki-laki berpendapat bahwa semuanya telah mengalir apa adanya tanpa ada unsur menuju perbedaan atau bias gender.

Narasi berupa ejekan atas keperawanan yang menjadi momok pengaturan laki-laki terhadap perempuan dilakukan Ayu Utami melalui tokoh Laila meskipun sosok ini mampu melawan gender keperempuanannya. Semasa sekolah dia paling banyak berlatih fisik. naik gunung, berkemah, turun tebing, cross country, dan melakukan kegiatan-kegiatan yang biasa dilakukan laki-laki. Ia lebih menyukai melakukan olah raga yang dilakukan laki-laki. Saat tidur pun bersisian dengan kawan lelaki dalam tenda dan perjalanan. Akan tetapi, dialah yang paling terlambat mengenal pria secara seksual. Pada masa itu ada rasa bangga bahwa dia memasuki dunia lelaki yang dinamis. Akan tetapi, semua yang dilakukan tokoh Laila bukanlah hal yang wajar dan diterima oleh masyarakat, tetapi justru menjadi hal yang tidak normatif. Ditunjukkan dalam kutipan berikut ini,

\footnotetext{
${ }^{6}$ Wiyatmi. Disharmonis Keluarga dalam Antologi Cerpen karya Perempuan. Makalah Seminar Sastra di Fakultas Bahasa dan Seni Universitas Negeri Yogyakarta. 2004. hlm. 3.
} 
”...tidak semua anak perempuan bisa melakukan itu, menyangkal hal-hal yang lembek, dan ia merasa ada supremasi pada dirinya.,"

Ternyata keadaan ini tidak dapat berubah hingga dewasa. Laila tidak bisa memasuki dunia lelaki dewasa. Keperawanan dan hak-haknya sebagai perempuan dia dapatkan, tetapi lelaki takut padanya. Laila sendiri pun mengalami keterlambatan libido. Oleh karena itu, akibat kekerasan dari dirinya untuk sejajar dengan dunia laki-laki dari segi konstruksi sosial menjadikan problema bagi dirinya sendiri. Budaya maupun masyarakat sendiripun kurang menerima keadaan Laila.

Kemajuan masyarakat dan kebudayaan telah membawa banyak perubahan diberbagai segi kehidupan, kemajauan, aktivitas tersebut tentu saja membawa dampak positif dan negatif. Salah satu dampak negatif alam ringkasan cerita di atas adalah timbulnya penolakan masyarakat terhadap keadaan feminimisme pada diri perempuan, lewat tokoh Laila, telah hilang.

Dengan adanya kenyataan tersebut, sebagian kecil masyarakat, terutama sastrawan berusaha mengungkap fenomena-fenomena kehidupan yang dilihat dan dialaminya ke dalam sebuah karya sastra. Hal ini sesuai dengan pendapat Suyitno (via Sugiarti $)^{8}$, menyatakan, bahwa "Salah satu pendorong lahirnya sebuah cipta sastra adalah fenomena lingkungan sosial dan konstruksi sosial yang membentuknya.

Setelah melihat beberapa fenomena teks narasi yang dihadirkan oleh penulis perempuan salah satu aspek terpenting dalam persoalan gender, adalah adanya hubungan erat antara gender dan konstruksi sosial masyarakat. Fenomena tersebut sangat jelas digambarkan melalui tokoh-tokoh yang diperankan dalam cerita.

Pengaruh tersebut dapat kita lihat dalam budaya dan aktivitas pada suatu masyarakat di linkungannya. Di satu sisi konstruksi sosial dapat di lihat melalui peran

\footnotetext{
${ }^{7}$ Utami, A. Laila. Jakarta: Kepustakaan Populer Gramedia. 2002. hlm. 118.

${ }^{8}$ Suyitno (via Sugiarti). Perempuan dan Budaya. http:/www. gender. com. Yogyakarta. htm. $1 / 25 / 2007$.
} 
atau aktivitas yang dimainkan kelompok-kelompok dalam sosial kemasyarakatan. Di sisi lain dapat kita tunjukkan pada status sosial kelompok-kelompok dalam masyarakat, seperti tingkat ekonomi, jabatan, pengahasilan, kekuasaan dan prestise (kebanggaan).

Selain itu, Ahmad Tohari dalam novelnya yang berjudul "Ronggeng Dukuh Paruh” juga menghadirkan cerita-cerita yang bernuansa gender, ikut meramaikan dunia sastra. Cerita tersebut berkisah tentang perjalanan seorang perempuan bernama Srinthil yang berprofesi menjadi penari tayub (lengger), dimana dia harus menjalani kehidupannya yang sarat dengan dilema permasalahan kekuasaan.

Melalui tokoh Srinthil, penulis hendak menyampaikan betapa beratnya menjadi perempuan Jawa sekitar abad 21. Kemolekan tubuh dan wajah Srinthil menjadikannya penari hebat yang mengundang sahwat laki-laki. Setiap pertunjukan Srinthil menari untuk memuaskan kesenangan laki-laki di atas panggung. Kemudian budaya patriarkhi (kehidupan lengger) di lingkungannya memaksa, agar Srithil rela mengorbankan keperawananya, sebagai syarat kesuksesan profesinya sebagi penari lengger di kampungnya. Akan tetapi, Srinthil meolak budaya tersebut sehingga dia dikucilkan dan di usir dari kehidupan sebagi penari lengger. Setelah diusir, Srinthil dengan segala keterbatasannya menjalani hidup dengan penuh kesusahan. Akhirnya Srinthil menemukan kekasih pujaaanya dan menikah, meskipun ekonomi hidupnya sangat memprihatinkan. Keteguhan Srinthil menolak budaya mengorbankan keperawanan sebagai syarat menjdi lengger, akhirnya dapat terwujudkan. Srinthil dapat menjaga kesuciannya sampai dia menikah dengan Darsa.

Dalam cerita novel berjudul “Ronggeng Dukuh Paruh” tersebut terdapat dekonstruksi kelompok perempuan dan budaya masyarakat. Keadaan tersebut menunjukkan posisi perempuan dikesampingkan dan dianggap kurang berguna dengan profesi sebagai penghibur laki-laki (lengger). Hal ini merupakan bukti 
bahawa perempuan di Indonesia masih menerima perlakuan yang tidak adil oleh budaya dan kaum laki-laki.

Struktur sosial masyarakat sejak dulu telah menempatkan kaum perempuan dalam posisi minoritas. Akan tetapi, dalam masyarakat modern sekarang ini, perempuan mempunyai status yang tinggi. Lai-laki dan perempuan mempunyai hak yang sama dan berbagi secara adil dalam hal memperoleh pendidikan, kekayaaan, tugas dan kekuasaan sekalipun.

Sejak manusia dilahirkan sudah menyandang kategori laki-laki atau perempuan. Jika seseorang dilahirkan laki-laki diharapakan setelah besar dan tinggal di masyarakat, mereka mempunyai peran sebagi laki-laki. Begutu juga wanita, diharapkan ketika hidup bermasyarakat akan berposisi sebagai perempuan dengan segala konsekuensinya. Konstruksi budaya tersebut sudah mengakar di masyarakat. Sastrawan melalui karyanya bermaksud mengubah persepsi tersebut agar menjadikan kaum perempuan sederajat dengan laki-laki dalam konstruksi sosial kemasyarakatan.

Dalam kehidupan sehari-hari kaum perempuan dan laki-laki selalu terjadi konflik dan permasalahan gender. Kaum perempuan berkeinginan untuk bergerak bebas secara leluasa untuk mendapatkan status dan menduduki peran penting di masyarakat. Akan tetapi, budaya masyarakat membatasi gerak kaum perempuan terutama setelah mereka menikah dan mempunyai anak. Pandangan masyarakat tentang perempuan yang sudah bersuami adalah merawat keluarga baik suaminya maupun anak-anaknya dengan baik.

Bedasarkan pandangan di atas, maka dapat diidentifikasi bahwa bias gender dan status sosial dalam masyarakat masih berlaku. Semakin besar perbedaan tersebut maka semakin besar pula permasalah itu tanpak, meskipun peran gender bukanlah satu-satunya penyebab permasalahan tersebut. 


\section{Ruang Estetika Sastra Karya Perempuan}

Pandangan masyarakat bahwa keindahan diperoleh dari feminimisme adalah kurang benar. Keindahan yang dimunculkan dalam cerita teks sastra berupa eksploitasi kefeminisan tubuh perempuan sebagai wahana penyampaian pesan kepada pembaca terutama kepada kaum laki-laki tidak sebatas pada kakaguman kemolekan fisik saja ${ }^{9}$. Jika persepsi masyarakat itu tidak diluruskan tentunya akan menjadi masalah bagi kehidupan teks sastra. Membaca teks sebagai pencerminan kenyataan belaka pasti sangat menyesatkan, tetapi membaca teks sebagai rekaan murni tidak kurang menyesatkannya. ${ }^{10}$

Teks sastra sebagai hasil dari pengendapan pengarang (terutama pengarang perempuan) dalam melihat dunia memungkinkan pengarang untuk mengomunikasikannya dengan pembaca. Lewat karya mereka mempunyai kemerdekaan dan kebebasan mengemukakan pendapat, keinginan, sekaligus tuntutan lewat tokoh-tokoh yang mereka ciptakan. Untuk memperkuat karakter tokoh yang diciptakan banyak unsur yang bisa digunakan, di antaranya adalah psikologi, moral, ekonomi, dan budaya. Mitos juga berperan dalam hal ini.

Psikologi akan membantu penulis untuk memahami manusia lebih sungguh, lebih jujur, dan tidak hanya dalam semangat manipulatif eksploitatif, melainkan dengan itikad memuliakan dan membahagiakan manusia khususnya perempuan seperti yang biasa juga dijanjikan lewat agama. Psikologi bisa menafsirkan, mengungkapkan gerak jiwa manusia, dan konflik batin secara lebih tuntas. Seorang psikoanalisis akan menafsirkan penyakit jiwa seorang pasien lewat ucapan-

${ }^{9}$ Fakih, Mansour. Analisis gender dan Transformasi Sosial. Yogyakarta. Pustaka Pelajar. 1996. hlm. 5.

${ }^{10}$ Teeuw, A. 1984. Sastra dan ilmu Sastra Pengantar Ilmu Sastra. Jakarta: Pusataka Jaya. hlm. 231. 
ucapannya, imajinasinya, demikian juga dengan sastra akan menafsirkan ungkapanungkapan bahasa teks tertentu karena teks sastra memungkinkan untuk mengungkapkan keinginan dan impian yang terpendam dengan cara yang dapat diterima oleh kesadaran.

Aktivitas ekonomi merupakan pembentukan kreativitas karya sastra seks yang di dalam nilai-nilai budaya ekonomi ditopengi tanda-tanda sensualitas, yang menciptakan semacam "erotisasi kebudayaan”. Berbagai bentuk khayalan lewat teks cerita diciptakan, yang mengondisikan orang memuja "kemolekan tubuh". Ekspresi kebebasan berkarya sastra dengan tema perempuan dijadikan media penumpahan keliaran libido laki-laki. Ekspresi perlawanan terhadap kekerasan tersamar dalam ranah konstruksi sosial dan seks perempuan, justru menjadi perangsang laki-laki untuk membacanya. Bukan untuk menyelami ketertekanan perempuan tapi sebagai media erotisme laki-laki. .Namun, memang tidak mudah meretas kultur yang telah tertanam kuat.

Karya-karya sastra perempuan tersebut sebagai media untuk memotivasi kaum perempuan agar melakukan sesuatu untuk menuangkan ide-ide yang dimiliki oleh perempuan, sehingga figur perempuan adalah sebagai bagian dari kehidupan ini yang patut diperhitungkan dan dibanggakan. Sekarang ini karya sastra perempuan hampir sejajar di kancah kesastraan Indonesia sebagai figur pembuktian bahwa kaum perempuan tidaklah lemah seperti anggapan masyarakat dan budaya patriarkhi.

\section{E. Penutup}

Kegiatan bersastra merupakan sebuah gambaran bagi sastrawan perempuan dalam menyikapi realita kehidupan perempuan dalam kesetaraan gender. Karya kreatif dalam karya sastra yang menjadi kajian di sini antara lain novel berjudul “Laila” karya Ayu Utami, antologi cerpen berjudul "Mereka Bilang Saya Monyet” 
karya Djenar Maesa Ayu dan novel berjudul “ Supernova” karya Dewi Dee. Ketiga karya tersebut ditulis oleh sastrawan perempuan dengan tema tentang dunia perempuan sebagai realita hegemoni dari laki.laki. Selain itu, sastrawan laki-laki yang menulis tentang dunia perempuan yaitu Ahmad Tohari dengan novelnya berjudul “Ronggeng Dukuh Paruh”. Dalam novelnya tersebut Ahmad Tohari ingin menggambarkan ketertindasan kaum perempuan dari konstruksi budaya dan ketertindasan dari kaum laki-laki.

Tema gender dalam karya sastra tersebut merupakan fenomena di masa lalu bahwa posisi perempuan diperlakukan tidak adil oleh laki-laki. Hal tersebut menjadi wacana bagi perempuan di masa sekarang ini untuk menyikapinya secara positif, seperti yang telah dilakukan oleh sastrawan muda perempuan masa sekarang ini. Sastrawan perempuan dengan segala keterbatasannya selalu ingin bangkit dan mengekspresikan ide-idenya ke dalam tulisan berupa karya sastra yang bertema dunia perempuan. Para sastrawan muda perempuan sekarang ini telah menduduki posisinya dalam kesetaraan gender selama mereka mampu menempatkan diri di panggung sastra. Profesi mereka sebagai sastrawan sesuai dengan pelaku gender akan menjadikan perjuangan ide-idenya sejajar dengan kaum laki-laki. 


\section{Daftar Pustaka}

Ahmadi, Abu. 2002. Psikologi Sosial. Jakarta: Rineka Cipta

Fakih, Mansour. 1996. Analisis gender dan Transformasi Sosial. Yogyakarta. Pustaka Pelajar

Maesa, Djenar A. 2002. Mereka Bilang Saya Monyet. Yogyakarta. Gramedia Pustaka Utama.

Nurgiyantoro, Burhan. Pengantar Pengkajian Fiksi. Yogayakarta.: Gajah Mada University Press.

Nasarudin.1999. Argumen Kesetaraan Jender. Jakarta: Paramadina.

Putraningsih, Titik. 2006. Pertunjukan Tari: Sebuah Kajian Perspektif gender. Yogyakarta: FBS UNY.

Sugiarti. 2007. Perempuan dan Budaya. www. gender. com. 10 Maret 2007

Teeuw, A. 1984. Sastra dan ilmu Sastra Pengantar Ilmu Sastra. Jakarta: Pusataka Jaya.

Utami, Ayu. 2002. Laila. Jakarta: Kepustakaan Populer Gramedia. . 2002. Saman. Jakarta. Kepustakaan Populer Gramedia.

Wiyatmi. 2004. Disharmonis Keluarga dalam Antologi Cerpen karya Perempuan. Makalah Seminar Sastra di Fakultas Bahasa dan Seni Universitas Negeri Yogyakarta. 